\title{
EXAMINATION OF THE ASSOCIATION BETWEEN HOUSING CONDITIONS AND PULMONARY TUBERCULOSIS IN GLASGOW
}

BY

\author{
J. S. MCMILLAN \\ Health and Welfare Department, Glasgow
}

It has been generally accepted that there is some association between unsatisfactory housing conditions and pulmonary tuberculosis. Lack of sunlight and deficient ventilation, often aggravated by overcrowding, may lower resistance, and overcrowding in the presence of an infectious case increases the risk of massive infection. High population density also favours the spread of infection. Yet the exact role played by poor housing in the incidence of pulmonary tuberculosis has been a matter of much speculation.

McKinlay (1947) drew attention to a "dissimilarity" in the trends of mortality from tuberculosis and of housing as measured by the average number of persons per room and the proportion of the population overcrowded over the 20 -year period 1911 to 1931 . He concluded that:

"... If adverse housing is in any way approaching the importance generally believed in determining the level of mortality from this disease, other factors must be operative-factors, moreover, which must be negatively correlated with the housing status (i.e., worst where housing is best) and of sufficient importance completely to obliterate in these data any evidence of a housing influence good or bad".

Stein (1950) studied the influence of socioeconomic conditions in Glasgow on the ward tuberculosis rates from 1930 to 1947 and concluded that:

"In the wards of Glasgow, the investigation of small, homogeneous areas reveals that the inequalities of incidence in this disease are very largely accounted for by disparities in social conditions. . . . The relationship of respiratory tuberculosis with the social complex demonstrates the important role played in Glasgow by housing conditions. Ordinary density of dwelling occupation, [average number of persons per house], together with overcrowding, represents the dominant influence in infection and in death from this disease".

On the other hand, however, Brett and Benjamin (1957), in a study of the association of housing conditions with the prevalence of tuberculosis in the Metropolitan Borough of Islington, found "no gradient in tuberculosis morbidity in relation to rising housing density".

In the present paper, notifications of pulmonary tuberculosis in Glasgow during 1951 and 1952 are examined in relation to housing conditions in the 37 wards of the city. A more detailed examination is made of notifications during 1951 in two districts of the city (each comprising two atjjacent wards), one with an exceptionally high and the other with a low incidence of the disease.

WARd CASE-RATES Related to Housing Conditions

Table I (opposite) gives the ward populations as at the 1951 Census (General Registry Office, Edinburgh, 1952), the ward case-rates for pulmonary tuberculosis per 10,000 of the population, adjusted for age and sex, for the combined years 1951 and 1952 , the difference between the adjusted ward rates and the city rate expressed in terms of the standard errors, the average number of rooms per house, the average number of persons per room, and the percentage of the 1951 population in private households living more than two persons per room. Adjusting factors for age and sex were calculated on the age and sex distributions of the ward populations at the 1951 Census, The adjusted ward case-rates for pulmonary tuberculosis per 10,000 of the population range from $10 \cdot 8$ to $28 \cdot 5$. Six wards have case-rates less than the city rate and three wards case-rates greater than the city rate by as much as twice the standard error.

The number of rooms per house has a high negative correlation and the number of persons per 
TABLE I

WARD CASE-RATES RELATED TO HOUSING CONDITIONS ADJUSTED FOR AGE AND SEX (GLASGOW 1951 AND 1952)

\begin{tabular}{|c|c|c|c|c|c|c|}
\hline \multicolumn{2}{|c|}{ City Wards } & \multirow{2}{*}{$\begin{array}{c}\text { Case-Rate } \\
\text { per } \\
10,000 \text { Population }\end{array}$} & \multirow{2}{*}{$\begin{array}{l}\text { Difference of Adjusted Ward } \\
\text { Case-Rates from City Rate } \\
\text { in Terms of Standard Errors } \\
x\end{array}$} & \multirow{2}{*}{$\begin{array}{c}\text { Rooms } \\
\text { per } \\
\text { House } \\
y_{1}\end{array}$} & \multirow{2}{*}{$\begin{array}{c}\text { Persons } \\
\text { per } \\
\text { Room } \\
y_{2}\end{array}$} & \multirow{2}{*}{$\begin{array}{c}\text { Percentage of Population in Private } \\
\text { Households (1951 Census) living } \\
\text { More than Two Persons per Room } \\
y_{3}\end{array}$} \\
\hline Number & Population & & & & & \\
\hline $\begin{array}{r}1 \\
2 \\
3 \\
4 \\
5 \\
6 \\
7 \\
8 \\
9 \\
10 \\
11 \\
12 \\
13 \\
14 \\
15 \\
16 \\
17 \\
18 \\
19 \\
20 \\
21 \\
22 \\
23 \\
24 \\
25 \\
26 \\
27 \\
28 \\
29 \\
30 \\
31 \\
32 \\
33 \\
34 \\
35 \\
36 \\
37\end{array}$ & $\begin{array}{l}42,609 \\
21,578 \\
40,621 \\
26,273 \\
40,171 \\
26,944 \\
24,235 \\
27,998 \\
35,649 \\
35,005 \\
20,089 \\
31,902 \\
23,758 \\
27,229 \\
26,946 \\
45,929 \\
28,817 \\
25,515 \\
21,032 \\
23,376 \\
26,814 \\
23,241 \\
30,198 \\
17,530 \\
30,965 \\
36,648 \\
26,895 \\
28,124 \\
35,152 \\
25,132 \\
40,448 \\
39,956 \\
22,529 \\
39,717 \\
26,377 \\
25,578 \\
21,787\end{array}$ & $\begin{array}{l}22 \cdot 5 \\
18 \cdot 1 \\
19 \cdot 2 \\
24 \cdot 7 \\
21 \cdot 9 \\
18 \cdot 5 \\
24 \cdot 9 \\
18 \cdot 9 \\
19 \cdot 4 \\
27 \cdot 3 \\
20 \cdot 7 \\
21 \cdot 4 \\
22 \cdot 2 \\
28 \cdot 5 \\
23 \cdot 0 \\
23 \cdot 6 \\
15 \cdot 0 \\
16 \cdot 7 \\
12 \cdot 2 \\
15 \cdot 7 \\
18 \cdot 7 \\
17 \cdot 8 \\
14 \cdot 2 \\
16 \cdot 6 \\
20 \cdot 7 \\
25 \cdot 5 \\
21 \cdot 4 \\
17 \cdot 6 \\
21 \cdot 1 \\
20 \cdot 2 \\
15 \cdot 6 \\
16 \cdot 0 \\
12 \cdot 7 \\
22 \cdot 5 \\
16 \cdot 5 \\
15 \cdot 1 \\
10 \cdot 8\end{array}$ & $\begin{array}{l}+0.91 \\
-0.80 \\
-0.61 \\
+1.48 \\
+0.59 \\
-0.73 \\
+1.53 \\
-0.60 \\
-0.50 \\
+2.78 \\
+0.03 \\
+0.33 \\
+0.56 \\
+2.91 \\
+0.87 \\
+1.51 \\
-1.91 \\
-1.38 \\
-2.48 \\
-1.58 \\
-0.65 \\
-0.91 \\
-2.49 \\
-1.18 \\
+0.07 \\
+2.13 \\
+0.31 \\
-1.09 \\
+0.25 \\
-0.14 \\
-2.21 \\
-2.01 \\
-2.42 \\
+0.90 \\
-1.40 \\
-1.85 \\
-3.02\end{array}$ & $\begin{array}{l}2 \cdot 63 \\
2 \cdot 66 \\
1 \cdot 90 \\
2 \cdot 24 \\
2 \cdot 05 \\
2 \cdot 87 \\
3 \cdot 32 \\
2 \cdot 11 \\
3 \cdot 01 \\
2 \cdot 28 \\
2 \cdot 67 \\
2 \cdot 41 \\
3 \cdot 94 \\
2 \cdot 08 \\
2 \cdot 25 \\
2 \cdot 89 \\
2 \cdot 52 \\
2 \cdot 52 \\
4 \cdot 16 \\
3 \cdot 74 \\
2 \cdot 45 \\
3 \cdot 12 \\
3 \cdot 34 \\
3 \cdot 45 \\
1 \cdot 81 \\
2 \cdot 36 \\
2 \cdot 34 \\
2 \cdot 43 \\
2 \cdot 37 \\
2 \cdot 55 \\
3 \cdot 88 \\
4 \cdot 41 \\
3 \cdot 44 \\
3 \cdot 43 \\
2 \cdot 56 \\
3 \cdot 90 \\
4 \cdot 01\end{array}$ & $\begin{array}{l}1 \cdot 47 \\
1 \cdot 37 \\
1 \cdot 80 \\
1 \cdot 58 \\
1 \cdot 73 \\
1 \cdot 16 \\
1 \cdot 22 \\
1 \cdot 59 \\
1 \cdot 40 \\
1 \cdot 51 \\
1 \cdot 35 \\
1 \cdot 50 \\
0 \cdot 89 \\
1 \cdot 72 \\
1 \cdot 51 \\
1 \cdot 46 \\
1 \cdot 26 \\
1 \cdot 42 \\
0 \cdot 68 \\
0.85 \\
1 \cdot 29 \\
1 \cdot 09 \\
1 \cdot 15 \\
1 \cdot 16 \\
1 \cdot 82 \\
1 \cdot 66 \\
1 \cdot 56 \\
1.41 \\
1 \cdot 62 \\
1 \cdot 38 \\
0.98 \\
0.98 \\
0 \cdot 84 \\
1 \cdot 30 \\
1 \cdot 22 \\
0.80 \\
0.78\end{array}$ & $\begin{array}{r}27 \cdot 3 \\
24 \cdot 0 \\
43 \cdot 2 \\
37 \cdot 2 \\
40 \cdot 8 \\
16 \cdot 2 \\
17 \cdot 3 \\
32 \cdot 2 \\
18 \cdot 6 \\
32 \cdot 3 \\
29 \cdot 4 \\
33 \cdot 2 \\
8 \cdot 6 \\
41 \cdot 6 \\
36 \cdot 4 \\
24 \cdot 2 \\
26 \cdot 8 \\
28 \cdot 0 \\
2 \cdot 0 \\
8 \cdot 4 \\
29 \cdot 6 \\
18 \cdot 5 \\
10 \cdot 1 \\
10 \cdot 4 \\
44 \cdot 2 \\
41 \cdot 9 \\
35 \cdot 1 \\
30 \cdot 5 \\
38 \cdot 6 \\
22 \cdot 3 \\
5 \cdot 2 \\
5 \cdot 7 \\
3 \cdot 5 \\
18 \cdot 5 \\
15 \cdot 6 \\
1 \cdot 4 \\
3 \cdot 8\end{array}$ \\
\hline City & $1,089,767$ & $20 \cdot 5$ & - & $2 \cdot 82$ & $1 \cdot 27$ & $24 \cdot 4$ \\
\hline
\end{tabular}

room and the percentage of the population living more than two per room (overcrowding) have high positive correlations with the ward incidence of pulmonary tuberculosis, expressed as the difference between the adjusted ward case-rates and the city rate in terms of the standard errors (Table II; Figs 1,2 , and 3 , overleaf).

The positive correlation with persons per room and with overcrowding is greater than the negative correlation with the average number of rooms per house. The association between these overcrowding indices and ward case-rates appears to be restricted to the 21 wards of the city with caserates less than the city rate: in the sixteen wards with case-rates greater than the city rate there is no significant correlation.

To examine in more detail the influence of housing conditions, two districts were selected for special study. One, District $A$, comprised the adjoining Wards 10 and 14 where the incidence of pulmonary tuberculosis was high, and the other, District B, the adjoining Wards 17 and 18 where the incidence was low. In 1951 the case-rate for pulmonary tuberculosis for the city was $20 \cdot 3$ per 10,000 of the
TABLE II

CORRELATION COEFFICIENTS CALCULATED FROM DATA IN TABLE I

Correlation Coefficients for the 37 Wards of the City

$$
\begin{array}{ll}
r_{x y_{1}}=-0.5519 & r_{y_{1} y_{2}}=-0.9169 \\
r_{x y_{2}}=0.6735 & r_{y_{1} y_{3}}=-0.9351 \\
r_{x y_{3}}=0.6687 & r_{y_{2} y_{3}}=0.9565
\end{array}
$$

Correlation Coefficients for the 21 Wards of the City having Case-Rates Less than the City Rate

$$
\begin{array}{ll}
r_{x^{\prime} y_{1}^{\prime \prime}}=-0.7220 & r_{y_{1}^{\prime} y_{2}}=-0.8973 \\
r_{x^{\prime} y^{\prime}{ }_{2}}=0.7553 & r_{y^{\prime} y_{1}}=-0.9303 \\
r_{x^{\prime} y_{3}{ }_{3}}=0.7167 & r_{y_{2}^{\prime} y_{3}^{\prime}}=0.9333
\end{array}
$$

Correlation Coefficients for the 16 Wards of the City having Case-Rates Greater than the City Rate

$$
\begin{aligned}
& r_{x^{n} y_{1}{ }_{1}}=-0.0898 \\
& r_{x^{\prime \prime} y_{2}}=0.1317 \\
& r_{y^{\prime \prime}{ }_{1}{ }^{\prime \prime}{ }_{8}}=-0.9443 \\
& r_{x^{\prime \prime} y_{3} n_{3}}=0.0890 \\
& r_{y^{\prime \prime}{ }_{1} y^{n_{3}}}=-0.9670 \\
& r_{y^{\prime \prime} y^{\prime \prime}}=0.9530
\end{aligned}
$$




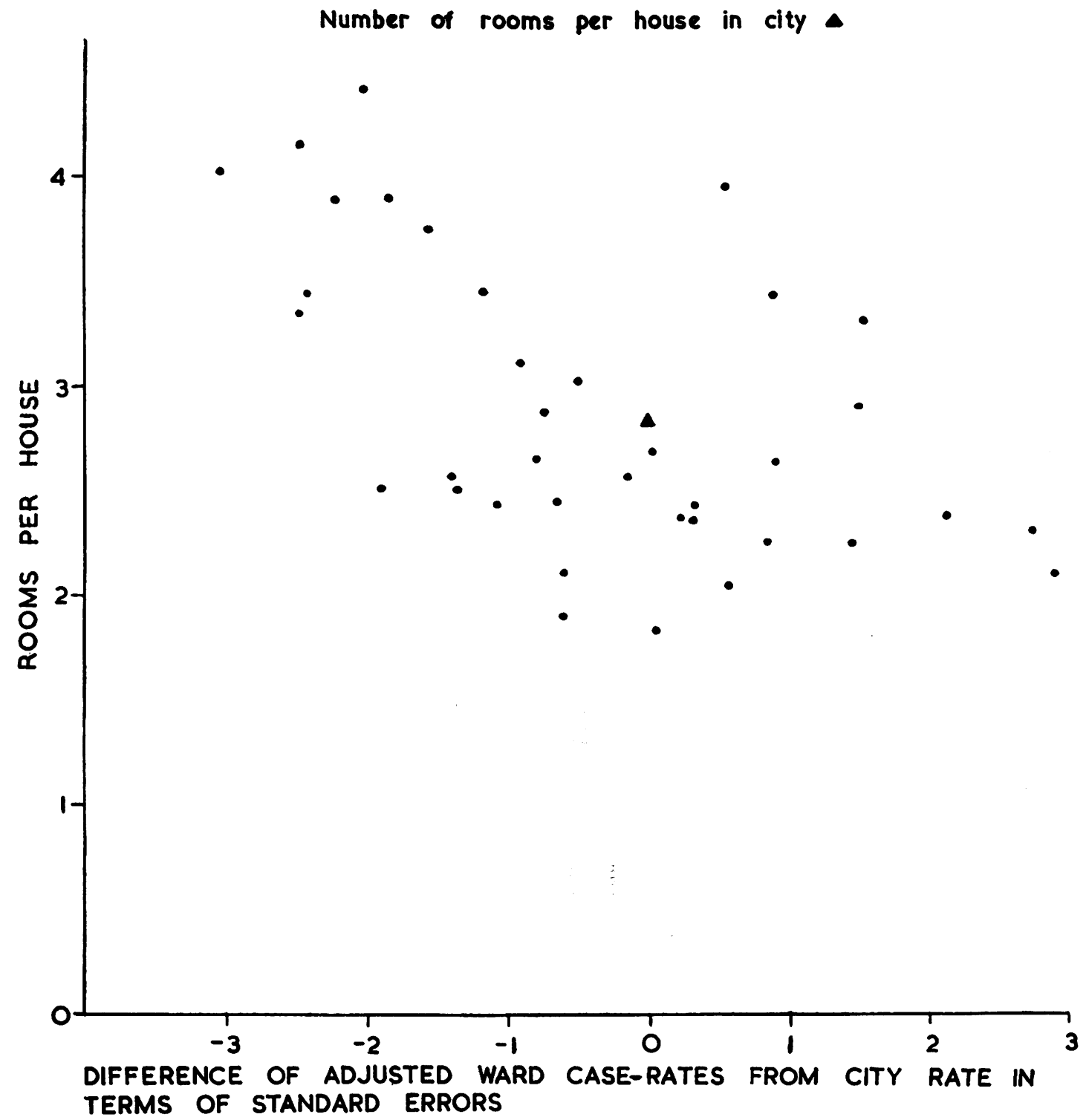

Fig. 1.-Adjusted ward case-rates for pulmonary tuberculosis (Glasgow, 1951 and 1952) expressed as the difference of the ward rates from the city rate in terms of the standard errors and the number of rooms per house.

population: in districts $A$ and $B$ it was $26 \cdot 1$ and 17.6 respectively. It must be remembered that at the Census in $1951,47 \cdot 3$ per cent. of houses in the city were of one and two rooms, so that, in addition to social and economic circumstances, availability of accommodation in Glasgow plays a large part in determining the size of house a family occupies (Table III, opposite).
When 1951 notifications in District A came to be individually reviewed, two errors were found in location of cases at the periphery of the district, and one case of tuberculous disease of the hip joint had been wrongly classified as respiratory disease. After these errors had been corrected, and two cases living in common lodging-houses had been excluded, there remained for analysis 156 notified cases in 


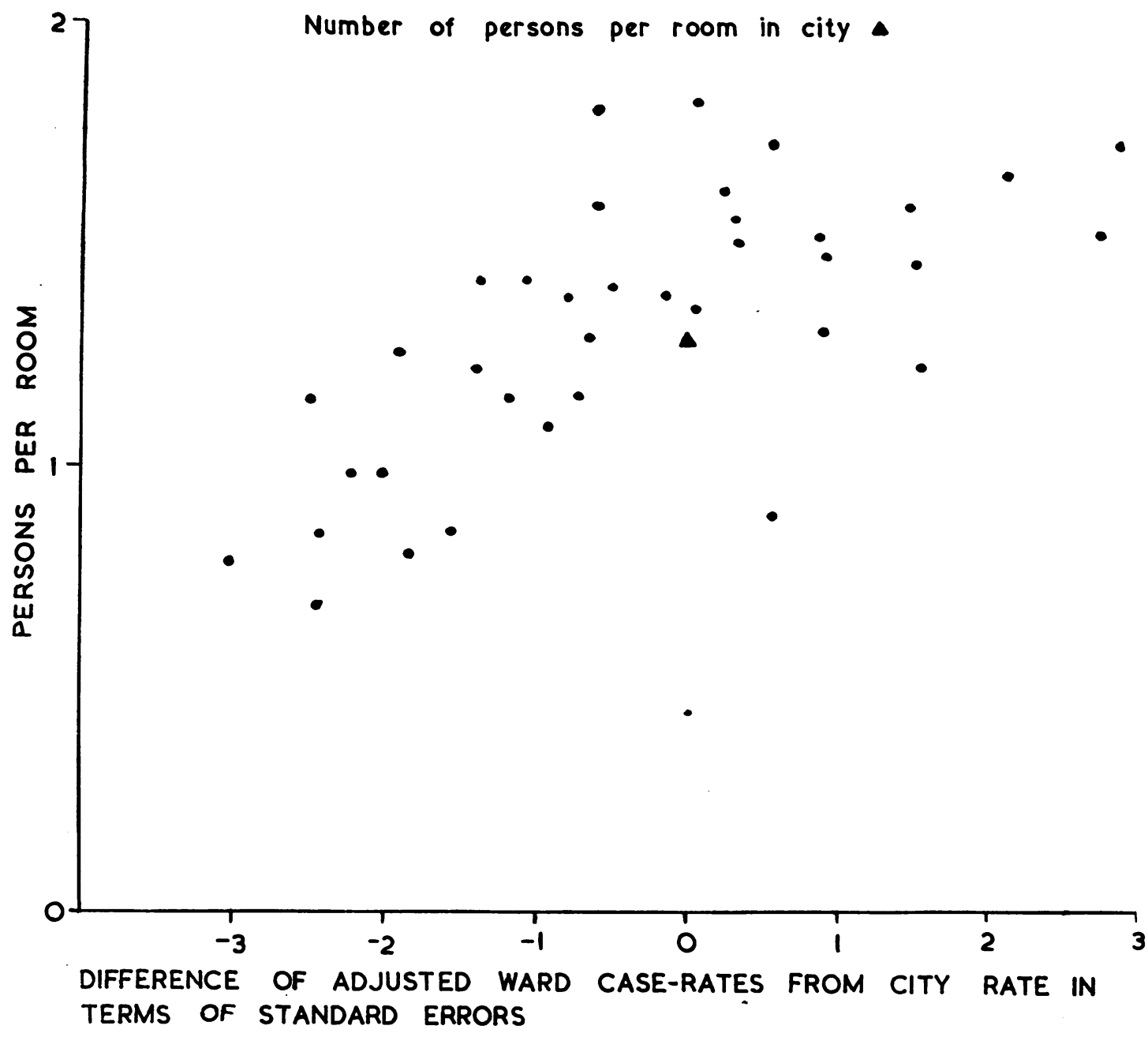

Fig. 2.-Adjusted ward case-rates for pulmonary tuberculosis (Glasgow, 1951 and 1952) expressed as the difference of the ward rates from the city rate in terms of the standard errors and the number of persons per room.

TABLE III

NUMBER OF ROOMS PER HOUSE IN DISTRICTS A AND B AND IN GLASGOW AS A WHOLE

\begin{tabular}{|c|c|c|c|c|c|c|c|c|c|}
\hline \multirow{2}{*}{\multicolumn{3}{|c|}{ Area }} & \multirow{3}{*}{$\begin{array}{c}\begin{array}{c}\text { Case-Rates } \\
\text { per } 10,000 \\
1951\end{array} \\
20 \cdot 3\end{array}$} & \multicolumn{5}{|c|}{ Percentage of Occupied Houses (1951 Census) with: } & \multirow{2}{*}{$\begin{array}{c}\text { No. of } \\
\text { Houses } \\
\text { in Area }\end{array}$} \\
\hline & & & & \multirow{2}{*}{$\frac{\text { One Room }}{11 \cdot 0}$} & \multirow{2}{*}{$\frac{\text { Two Rooms }}{36 \cdot 3}$} & \multirow{2}{*}{$\frac{\text { Three Rooms }}{28 \cdot 2}$} & \multirow{2}{*}{$\begin{array}{c}\begin{array}{c}\text { Four Rooms } \\
\text { and Over }\end{array} \\
24 \cdot 5\end{array}$} & \multirow{2}{*}{$\frac{\text { All Houses }}{100 \cdot 0}$} & \\
\hline Glasgow & $\ldots$ & $\ldots$ & & & & & & & 294,467 \\
\hline$\overline{\text { District A }}$ & $\ldots$ & $\ldots$ & $26 \cdot 1$ & $16 \cdot 7$ & $55 \cdot 6$ & $21 \cdot 9$ & $5 \cdot 8$ & $100 \cdot 0$ & 17,044 \\
\hline$\overline{\text { District B }}$ & .. & $\ldots$ & $17 \cdot 6$ & $11 \cdot 8$ & $49 \cdot 1$ & $26 \cdot 3$ & $12 \cdot 7$ & $100 \cdot 0$ & 14,915 \\
\hline
\end{tabular}

District $\mathrm{A}$ and 88 notified cases in District B. In the analysis which follows the terms "tuberculous cases", "tuberculous houses", and "tuberculous house- holds" refer to these notified cases and to the houses and households in which they lived. It has not been possible to allow for age and sex. 


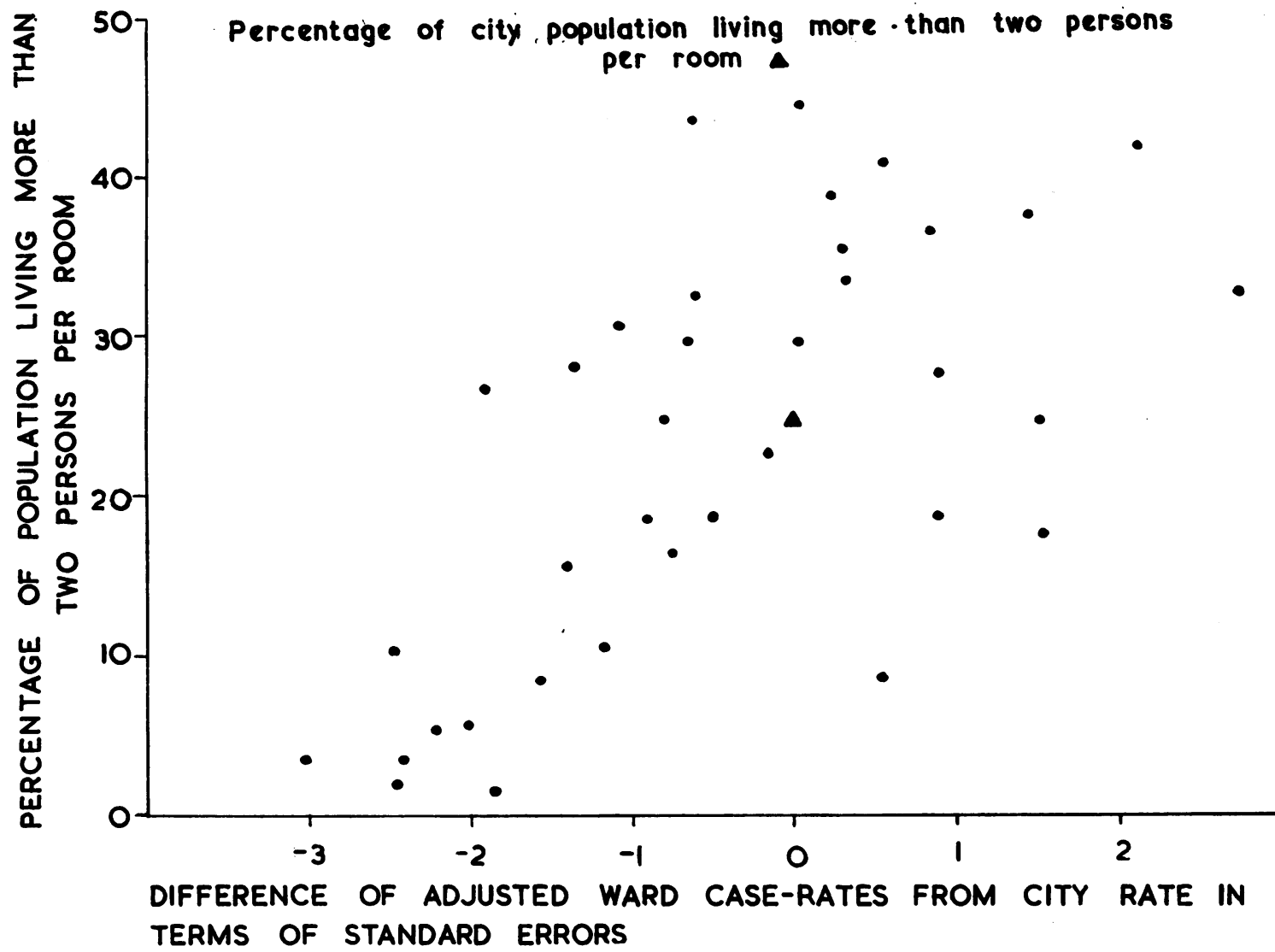

FIG. 3.-Adjusted ward case-rates for pulmonary tuberculosis (Glasgow, 1951 and 1952) expressed as the difference of the ward rates from the city rate in terms of the standard errors and the percentage of the population living more than two persons per room.

Number OF ROOMS IN TUberculous Houses AND NuMBER OF ROOMS OCCUPIED BY HOUSEHOLDS OF Tuberculous CASES

The number of houses of one, two, three, and four or more rooms, and of households occupying one, two, three, and four or more rooms, with the number of persons occupying corresponding accommodation are given in Table IV (opposite) with the notifications of pulmonary tuberculosis in 1951 and the caserates per 10,000 of the population. The case-rates in houses of one room and of four or more rooms and in households occupying one room and four or more rooms in District A may appear somewhat high, but the numbers are small and the differences not significant.

Tables V and VI (opposite) give the observed and expected numbers of notifications according to rooms per house and rooms per household; the expected number is based on the proportion of the district populations (Census, 1951) living in corresponding accommodation. In the two districts, though the numbers are small, there is no evidence that either the number of rooms in the tuberculous house or the number of rooms occupied by the tuberculous household has influenced the incidence of the disease.

Size OF FAMILY AND OVERCROWDING.-Irrespective of the number of rooms occupied, the average number of persons in tuberculous households was, in both districts, consistently greater than that in private households generally (Table VII, opposite).

In 1951, 14.9 per cent. of the population in Glasgow were in the age group 15-24 years, but this age group accounted for 34 per cent. of the notifications of pulmonary tuberculosis (Table VIII, opposite). Only 16 per cent. of the persons in this age group were married, compared with 69 per cent. of 
TABLE IV

PRIVATE hOUSES, PERSONS IN PRIVATE HOUSES, PRIVATE HOUSEHOLDS, AND PERSONS IN PRIVATE HOUSEHOLDS (1951 CENSUS) RELATED TO NOTIFICATIONS

\begin{tabular}{|c|c|c|c|c|c|c|c|c|c|}
\hline \multirow[b]{2}{*}{ District } & & \multicolumn{4}{|c|}{$\mathbf{A}$} & \multicolumn{4}{|c|}{ B } \\
\hline & & $\begin{array}{l}\text { No. of } \\
\text { Private } \\
\text { Houses }\end{array}$ & $\begin{array}{l}\text { No. of } \\
\text { Persons }\end{array}$ & $\begin{array}{l}\text { No. of } \\
\text { Tuberculous } \\
\text { Cases }\end{array}$ & $\begin{array}{l}\text { Case-Rate } \\
\text { per } 10,000\end{array}$ & $\begin{array}{l}\text { No. of } \\
\text { Private } \\
\text { Houses }\end{array}$ & $\begin{array}{l}\text { No. of } \\
\text { Persons }\end{array}$ & $\begin{array}{c}\text { No. of } \\
\text { Tuberculous } \\
\text { Cases }\end{array}$ & $\begin{array}{l}\text { Case-Rate } \\
\text { per } 10,000\end{array}$ \\
\hline $\begin{array}{l}\text { No. of Rooms } \\
\text { in House }\end{array}$ & $\begin{array}{c}1 \\
2 \\
3 \\
\text { and }\end{array}$ & $\begin{array}{r}2,839 \\
9,482 \\
3,732 \\
991\end{array}$ & $\begin{array}{r}7,568 \\
32,204 \\
14,830 \\
5,088\end{array}$ & $\begin{array}{l}24 \\
74 \\
39 \\
19\end{array}$ & $\begin{array}{l}31 \cdot 7 \\
23 \cdot 0 \\
26 \cdot 3 \\
37 \cdot 3\end{array}$ & $\begin{array}{l}1,766 \\
7,323 \\
3,930 \\
1,896\end{array}$ & $\begin{array}{r}4,617 \\
23,303 \\
14,443 \\
7,701\end{array}$ & $\begin{array}{r}6 \\
45 \\
25 \\
12\end{array}$ & $\begin{array}{l}13 \cdot 0 \\
19 \cdot 3 \\
17 \cdot 3 \\
15 \cdot 6\end{array}$ \\
\hline Total Houses ... & . & 17,044 & 59,690 & 156 & $26 \cdot 1$ & 14,915 & 50,064 & 88 & $17 \cdot 6$ \\
\hline $\begin{array}{l}\text { No. of Rooms } \\
\text { occupied by } \\
\text { Household }\end{array}$ & $\begin{array}{c}1 \\
2 \\
3 \\
\text { and }\end{array}$ & $\begin{array}{r}3,648 \\
9,556 \\
3,630 \\
856\end{array}$ & $\begin{array}{r}9,555 \\
32,139 \\
14,070 \\
3,926\end{array}$ & $\begin{array}{l}33 \\
73 \\
35 \\
15\end{array}$ & $\begin{array}{l}34 \cdot 5 \\
22 \cdot 7 \\
24 \cdot 9 \\
38 \cdot 2\end{array}$ & $\begin{array}{l}2,274 \\
7,427 \\
3,873 \\
1,823\end{array}$ & $\begin{array}{r}5,752 \\
23,441 \\
13,956 \\
6,915\end{array}$ & $\begin{array}{l}11 \\
45 \\
21 \\
11\end{array}$ & $\begin{array}{l}19 \cdot 1 \\
19 \cdot 2 \\
15 \cdot 0 \\
15 \cdot 9\end{array}$ \\
\hline Total Households & . & 17,690 & 59,690 & 156 & $26 \cdot 1$ & 15,397 & 50,064 & 88 & $17 \cdot 6$ \\
\hline
\end{tabular}

TABLE V

NOTIFICATIONS ACCORDING TO ROOMS PER HOUSE

\begin{tabular}{|c|c|c|c|c|c|}
\hline \multirow{3}{*}{ District } & & \multirow{2}{*}{\multicolumn{2}{|c|}{$\frac{\text { A }}{\text { Notifications }}$}} & \multirow{2}{*}{\multicolumn{2}{|c|}{$\frac{\text { B }}{\text { Notifications }}$}} \\
\hline & & & & & \\
\hline & & Observed & Expected ${ }^{*}$ & Observed & Expected* \\
\hline $\begin{array}{l}\text { No. of } \\
\text { Rooms } \\
\text { per } \\
\text { House }\end{array}$ & $\begin{array}{c}1 \\
2 \\
3 \\
4 \text { and Over }\end{array}$ & $\begin{array}{l}24 \\
74 \\
39 \\
19\end{array}$ & $\begin{array}{l}19 \cdot 8 \\
84 \cdot 2 \\
38 \cdot 8 \\
13 \cdot 3\end{array}$ & $\begin{array}{r}6 \\
45 \\
25 \\
12\end{array}$ & $\begin{array}{r}8 \cdot 1 \\
41 \cdot 0 \\
25 \cdot 4 \\
13 \cdot 5\end{array}$ \\
\hline \multicolumn{2}{|c|}{ Total Private Houses } & 156 & $156 \cdot 0$ & 88 & $88 \cdot 0$ \\
\hline
\end{tabular}

* The expected number is based on the House Population (Census).

District $B: \chi_{3}^{2}=1.11 ; 0.7<P<0.8$

TABLE VI

NOTIFICATIONS ACCORDING TO ROOMS PER HOUSEHOLD

\begin{tabular}{|c|c|c|c|c|c|}
\hline \multirow{3}{*}{ District } & & \multirow{2}{*}{\multicolumn{2}{|c|}{$\frac{\text { A }}{\text { Notifications }}$}} & \multirow{2}{*}{\multicolumn{2}{|c|}{$\frac{\text { B }}{\text { Notifications }}$}} \\
\hline & & & & & \\
\hline & & Observed & Expected * & Observed & Expected* \\
\hline \multirow{2}{*}{$\begin{array}{l}\text { No. of } \\
\text { Rooms } \\
\text { Occupied } \\
\text { by } \\
\text { House- } \\
\text { hold }\end{array}$} & $\begin{array}{l}1 \\
2 \\
3 \\
4\end{array}$ & $\begin{array}{l}33 \\
73 \\
35\end{array}$ & $\begin{array}{l}.25 \cdot 0 \\
84 \cdot 0 \\
36 \cdot 8\end{array}$ & $\begin{array}{l}11 \\
45 \\
21\end{array}$ & $\begin{array}{l}10 \cdot 1 \\
41 \cdot 2 \\
24 \cdot 5\end{array}$ \\
\hline & Over & 15 & $10 \cdot 3$ & 11 & $12 \cdot 2$ \\
\hline \multicolumn{2}{|c|}{$\begin{array}{c}\text { Total Private } \\
\text { Households }\end{array}$} & 156 & $156 \cdot 0$ & 88 & $88 \cdot 0$ \\
\hline
\end{tabular}

* The expected number is based on the Household Population (Census) District $A: \chi_{2}^{2}=6.23 ; 0.1<P<0.2$

District $B: \chi^{2_{3}^{2}}=1.05 ; 0.7<P<0.8$ District $A: \chi_{2}^{2}=4.57 ; 0.2<P<0.3$

TABLE VII

AVERAGE NUMBER OF PERSONS PER HOUSEHOLD

\begin{tabular}{|c|c|c|c|c|c|}
\hline \multirow[b]{2}{*}{ District } & & \multicolumn{2}{|c|}{$\mathbf{A}$} & \multicolumn{2}{|c|}{ B } \\
\hline & & $\begin{array}{c}\text { All } \\
\text { Private } \\
\text { House- } \\
\text { holds }\end{array}$ & $\begin{array}{l}\text { Tuber- } \\
\text { culous } \\
\text { House- } \\
\text { holds }\end{array}$ & $\begin{array}{c}\text { All } \\
\text { Private } \\
\text { House- } \\
\text { holds }\end{array}$ & $\begin{array}{l}\text { Tuber- } \\
\text { culous } \\
\text { House- } \\
\text { holds }\end{array}$ \\
\hline \multirow{2}{*}{$\begin{array}{l}\text { No. of } \\
\text { Rooms } \\
\text { Occupied } \\
\text { by House- } \\
\text { hold }\end{array}$} & \multirow{2}{*}{$\begin{array}{c}1 \\
2 \\
3 \\
4 \text { and } \\
\text { Over }\end{array}$} & $\begin{array}{l}2.6 \\
3.4 \\
3.9\end{array}$ & $\begin{array}{l}3 \cdot 3 \\
4 \cdot 0 \\
4 \cdot 8\end{array}$ & $\begin{array}{l}2 \cdot 5 \\
3 \cdot 2 \\
3 \cdot 6\end{array}$ & $\begin{array}{l}2 \cdot 8 \\
4 \cdot 2 \\
5 \cdot 7\end{array}$ \\
\hline & & $4 \cdot 6$ & $5 \cdot 8$ & $3 \cdot 8$ & $5 \cdot 6$ \\
\hline \multicolumn{2}{|c|}{ All Households } & $3 \cdot 4$ & $4 \cdot 2$ & $3 \cdot 3$ & $4 \cdot 5$ \\
\hline
\end{tabular}

those in the following decade. Families with adolescent and young adult members, of whom only a small proportion are married, are usually approaching their maximum size, and since the incidence of disease in the adolescent and young adult age group is high, it would appear to follow that the average size of families in which a case of pulmonary tuberculosis had occurred would necessarily be larger than the average size of other families in the area.

Where the number of rooms per house in an area is small, it is to be expected, if the average tuberculous household is larger than the average household, that tuberculous households will show more overcrowding. A comparison of the proportion of tuberculous cases overcrowded with the proportion of the

TABLE VIII

PERCENTAGE OF POPULATION AND OF NOTIFICATIONS OF PULMONARY TUBERCULOSIS BY AGE GROUP AND SEX, GLASGOW, 1951

\begin{tabular}{|c|c|c|c|c|c|c|c|c|}
\hline \multirow{2}{*}{\multicolumn{2}{|c|}{ Sex }} & \multicolumn{2}{|c|}{ Male } & \multicolumn{2}{|c|}{ Female } & \multicolumn{2}{|c|}{ Both } & \multirow{2}{*}{$\begin{array}{c}\text { Per cent. of } \\
\text { Population } \\
\text { Married }\end{array}$} \\
\hline & & Population & Notifications & Population & Notifications & Population & Notifications & \\
\hline \multirow[t]{2}{*}{$\underset{\substack{\text { Age } \\
\text { (yrs) }}}{\text { (yroup }}$} & 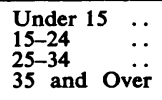 & $\begin{array}{l}26 \cdot 4 \\
14 \cdot 5 \\
14 \cdot 8 \\
44 \cdot 3\end{array}$ & $\begin{array}{l}10 \cdot 9 \\
26 \cdot 3 \\
16 \cdot 2 \\
46 \cdot 6\end{array}$ & $\begin{array}{l}23 \cdot 4 \\
15 \cdot 2 \\
14 \cdot 4 \\
47 \cdot 0\end{array}$ & $\begin{array}{l}14 \cdot 7 \\
42 \cdot 7 \\
22 \cdot 9 \\
19 \cdot 7\end{array}$ & $\begin{array}{l}24 \cdot 8 \\
14 \cdot 9 \\
14 \cdot 6 \\
45 \cdot 7\end{array}$ & $\begin{array}{l}12 \cdot 7 \\
34 \cdot 0 \\
19 \cdot 4 \\
33 \cdot 9\end{array}$ & $\begin{array}{l}\overline{16 \cdot 0} \\
69 \cdot 0 \\
67 \cdot 9\end{array}$ \\
\hline & All Ages & $100 \cdot 0$ & $100 \cdot 0$ & $100 \cdot 0$ & $100 \cdot 0$ & $100 \cdot 0$ & $100 \cdot 0$ & $43 \cdot 5$ \\
\hline
\end{tabular}


population overcrowded may be expected to yield evidence of the association of tuberculosis with overcrowding, but, on the basis of the previous argument, the overcrowded population in an area would be likely to contain a larger proportion of adolescents and young adults. Therefore, to get a true estimate of the importance of overcrowding as a factor, an adjustment for the age and sex of the population overcrowded and of the population not overcrowded would be required. The data for such an adjustment were not available in the present analysis.

OVERCROWDING.--In District A, $36 \cdot 8$ per cent. of the total population but only $29 \cdot 5$ per cent. of the tuberculous cases were overcrowded (i.e. living more than two persons per room). Of all private households in the district, 23.4 per cent. were overcrowded compared with $29 \cdot 5$ per cent. of tuberculous households. These differences are not statistically significant. In District $B$, on the other hand, 27.5 per cent. of the total population and 37.5 per cent. of tuberculous cases were overcrowded, as were 17 per cent. of private households and $37 \cdot 2$ per cent. of tuberculous households. The difference in both these instances is significant of an association between pulmonary tuberculosis and overcrowding.

Over one-half of households in the city (Census 1951) occupied one or two rooms and of these oneand two-roomed households $44 \cdot 5$ and 18.9 per cent. respectively were overcrowded. As the number of rooms increases, the percentage of overcrowding falls rapidly. It is, therefore, the households living in one and two rooms that contribute largely to the state of overcrowding in the city. And if overcrowding per se had been the important factor, an appreciably higher proportion of households occupying one and two rooms might have been expected to be attacked. In District B 64.0 per cent. of tuberculous households and 63.0 per cent. of all households occupied no more than two rooms, and no association was found between the number of rooms occupied by the household and the occurrence of tuberculosis.

It would appear that the association with overcrowding in District B merely reflected the larger size of the tuberculous family and that the population in both districts shared in the general incidence of the disease in the district independent of overcrowding.

Contact Cases and Overcrowding.-The term "contact case" refers to a case of pulmonary tuberculosis living at the time of onset or within 5 years of onset in the same house as a case of pulmonary tuberculosis (Table IX). In $89 \cdot 1$ per cent. of the contact cases as thus defined, the previous case was a member of the patient's immediate family. In no instance had a contact been rehoused under the tuberculosis scheme. Since there was no appreciable difference in the proportion of contact cases occurring in the two districts, they were considered together for the purpose of this section. Where two cases were notified in a household during the year and the first case was a primary notification, the household was recorded twice, it was recorded only once where more than one contact case arose.

When overcrowding (more than two persons per room) in the households of contact cases was compared with overcrowding in those households where there had been no previous case $(33.3$ and 32.4 per cent. respectively), no significant association with overcrowding was found (Table X, opposite).

In 26 households, the contact was living in the same house with a case of pulmonary tuberculosis at the time of onset; in fifteen of these households (four living more than two persons per room), contact was with a sputum-positive case, and in the remaining eleven (six living more than two persons per room), contact was with a sputum-negative case.

TABLE IX

CONTACT CASES OF PULMONARY TUBERCULOSIS LIVING AT TIME OR WITHIN 5 YEARS OF ONSET IN SAME HOUSE, WITH A CASE OF PULMONARY TUBERCULOSIS

(Numbers of households affected are given in brackets)

\begin{tabular}{|c|c|c|c|c|c|c|c|c|c|c|}
\hline \multirow{3}{*}{ District } & & & \multicolumn{4}{|c|}{$\mathbf{A}$} & \multicolumn{4}{|c|}{ B } \\
\hline & & & \multicolumn{2}{|c|}{ Sputum } & \multirow{2}{*}{ All Cases } & \multirow{2}{*}{$\begin{array}{l}\text { Per Cent. } \\
\text { of Total }\end{array}$} & \multicolumn{2}{|c|}{ Sputum } & \multirow{2}{*}{ All Cases } & \multirow{2}{*}{$\begin{array}{l}\text { Per Cent. } \\
\text { of Total }\end{array}$} \\
\hline & & & Positive & Negative & & & Positive & Negative & & \\
\hline \multirow{3}{*}{$\begin{array}{r}\text { History of } \\
\text { Contact }\end{array}$} & $\begin{array}{l}\text { At Onset } \ldots \text {. } \\
\text { Within } 5 \text { years of Onset }\end{array}$ & . & $\begin{array}{l}13(11) \\
12(12)\end{array}$ & $\begin{array}{ll}8 & (8) \\
4 & (4)\end{array}$ & $\begin{array}{l}21(19) \\
16(16)\end{array}$ & $\begin{array}{l}13 \cdot 6(12 \cdot 4) \\
10 \cdot 3(10 \cdot 5)\end{array}$ & $\begin{array}{ll}5 & (4) \\
6 & (6)\end{array}$ & $\begin{array}{l}4(3) \\
3(3)\end{array}$ & $\begin{array}{ll}9 & (7) \\
9 & (9)\end{array}$ & $\begin{array}{ll}10 \cdot 2 & (8 \cdot 1 \\
10 \cdot 2 & (10 \cdot 5)\end{array}$ \\
\hline & $\begin{array}{c}\text { No Contact } \\
\text { Defined } \ldots \\
\text { History }\end{array}$ & as & - & - & $118(118)$ & $76 \cdot 1 \quad(77 \cdot 1)$ & - & - & 70 (70) & $79 \cdot 6(81 \cdot 4)$ \\
\hline & All Cases & $\ldots$ & $25(23)$ & $12(12)$ & $155 *(153)$ & $100 \cdot 0(100 \cdot 0)$ & $11(10)$ & 7 (6) & $88 \quad(86)$ & $100 \cdot 0(100 \cdot 0)$ \\
\hline
\end{tabular}

* One case excluded, a widow, who lived alone and who died in a general hospital, and of whom no information as to previous contact was available. 
TABLE X

COMPARISON OF OVERCROWDING IN HOUSEHOLDS OF "CONTACT" CASES WITH HOUSEHOLDS OF CASES HAVING "NO CONTACT"

\begin{tabular}{|c|c|c|c|c|c|}
\hline \multirow{2}{*}{$\begin{array}{c}\text { No. of } \\
\text { Persons } \\
\text { Living } \\
\text { per Room }\end{array}$} & \multicolumn{3}{|c|}{ Contact Households } & \multirow{2}{*}{$\begin{array}{c}\text { House- } \\
\text { holds } \\
\text { with "No } \\
\text { Contact" }\end{array}$} & \multirow{2}{*}{$\begin{array}{l}\text { All } \\
\text { Tuberculous } \\
\text { Households }\end{array}$} \\
\hline & $\begin{array}{c}\text { All } \\
\text { Cases }\end{array}$ & $\begin{array}{c}\text { Sputum } \\
+\end{array}$ & Sputum & & \\
\hline $\begin{array}{l}\text { More than } \\
\text { Two }\end{array}$ & 17 & 10 & 7 & 61 & 78 \\
\hline $\begin{array}{l}\text { Not more } \\
\text { than Two }\end{array}$ & 34 & 23 & 11 & 127 & 161 \\
\hline $\begin{array}{l}\text { All House- } \\
\text { holds }\end{array}$ & 51 & 33 & 18 & 188 & 239 \\
\hline $\begin{array}{l}\text { Percentage } \\
\text { Overcrowded }\end{array}$ & $33 \cdot 3$ & $30 \cdot 3$ & $38 \cdot 9$ & $32 \cdot 4$ & $32 \cdot 6$ \\
\hline
\end{tabular}

These numbers do not reveal any association between overcrowding in the households of contact cases as compared with overcrowding in households where there had been no previous case.

The total number of persons in the households of contact cases of pulmonary tuberculosis was 282 , of whom 172 lived not more than two persons per room. In the group of 172 persons who were not overcrowded, there were 37 contact cases $(21.5$ per cent.), while in the remaining group of 110 persons who were overcrowded, there were eighteen contact cases ( 16.4 per cent.). Again no association between the incidence of contact cases of pulmonary tuberculosis and overcrowding is present.

While no association between the occurrence of contact cases of pulmonary tuberculosis and overcrowding has been established, the problem is complicated by the rehousing of patients in an actively infectious stage who were unable to have a room to themselves, and further complicated by delays in rehousing from financial reasons and from difficulties in meeting the wishes of the patient and his family in such matters as distance from work, nearness of relatives, and congeniality of surroundings. Any conclusions as to the influence of overcrowding must be treated with reserve.

The risk to household contacts with persons suffering from pulmonary tuberculosis is very great. The 244 cases notified from the two districts in 1951, included 55 cases living or having lived within 5 years of onset in the same house with a case of pulmonary tuberculosis, and in 26 households the person or persons with whom the case or cases had been in contact was still living there. These 244 cases were associated with 767 household contacts. The 55 new contact cases occurred among 796 family contacts of known cases of pulmonary tuberculosis, which gives a case-rate of 691 per 10,000 . The total population of the two districts was 109,754 , and in this population 244 cases were notified, giving a case-rate of $22 \cdot 2$ per 10,000 . Thus the estimated case-rate in family contacts is about thirty times that in the general population.

\section{Fitness of a House as a Possible Influence on}

\section{THE INCIDENCE OF PUlmonary TUBerculosis}

Ward 10 of District A was surveyed in detail as to the standard of housing in 1949, and Ward 14 in 1950. Measures were taken, as far as was practicable, to keep the surveys up-to-date, and the figures quoted are for the end of 1951. Ward 18 of District B was surveyed in the latter half of 1952. Ward 17 of District B was not surveyed and has been excluded from the analysis. It was known that in Ward 17 there were only 47 unfit houses, twenty of one room, 26 of two rooms, and one of three rooms. The built-up area of Ward 18 covered only a part of the total area of the Ward. A squatters' camp, remote from the built-up area and with separate access to the City, in which no case of tuberculosis was notified in 1951, has been excluded from the survey figures, as have the houses of the married quarters of Maryhill Barracks.

There is a small discrepancy of 1 per cent. between the total number of houses in the survey and the number obtained at the Census in both wards of District A, and in Ward 18 of District B.

Classification of Houses.-For the purpose of these surveys the houses were classified according to four standards:

Standard.-Houses containing all modern conveniences, including separate water-closet, bathroom, adequate food storage accommodation, adequate cooking facilities, and hot and cold water supply. Such houses seldom have less than three rooms.

Substandard " $A$ ".- - Houses falling short in some degree of the standard house, but situated in a building of good fabric which could be adapted to provide houses of standard type. Such houses may have only one room.

Substandard " $B$ ".- Houses which, while not considered unfit, are unsatisfactory. They fall short of the standard type, and because of the age of the building and the condition of the fabric are not suitable for reconstruction.

Unfit.-Houses unfit for human habitation because of defective design or the degree of sanitary defects existing or both. 
Table XI shows the distribution and the percentage distribution according to the type of house in District A and Ward 18 of District B for houses occupied by tuberculous families, for all houses in the area, for the tuberculous cases, and for the estimated population.

The actual numbers of persons living in houses of different types were not available; these were estimated by multiplying the number of houses, according to rooms and type, by the average number of persons occupying houses of corresponding size in the areas. There was no obvious association between the incidence of pulmonary tuberculosis and the fitness or otherwise of a house, but in Ward 18 of District $B$ the number of houses involved was small.

This question was explored further by dividing the houses of District A and of Ward 18 of District B into two groups:

(1) Satisfactory, when the houses were of standard type or were classed as Substandard " $A$ " or "B" with three or more rooms;

(2) Unsatisfactory, when the houses were classed as Substandard "A" or " $B$ " with only one or two rooms, or as unfit.

With such a grouping the percentage of satisfactory houses among those occupied by tuberculous families was found to be higher than the percentage satisfactory of all houses both in District A and in Ward 18 of District B (33.6 per cent. compared with 29.2 per cent., and 60.8 per cent. compared with 49.4 per cent. respectively). Thus the occurrence of pulmonary tuberculosis would appear to be independent of the fitness, or otherwise, of the house.

\section{Discussion}

In Glasgow at the present time, for those wards of the city in which the incidence of pulmonary tuberculosis is less than for the city as a whole, there is a high correlation between ward case-rates and the average number of rooms per house, the average number of persons per room, and the percentage of the population living more than two persons per room; for those wards of the city with a high incidence of disease there is no significant correlation with these overcrowding indices. This finding, taken in conjunction with the apparent absence of association with any particular aspect of individual housing in localized areas, suggests that in those wards of the city where the incidence of disease is high, factors must be operative which overshadow housing conditions in importance.

The larger size of the average tuberculous household, the association of tuberculosis with population density, and, in those wards of the city with high prevalence, the operation of factors other than housing will help to reconcile the somewhat conflicting views that have been expressed as to the role of housing in tuberculosis.

If the influence of housing is largely the result of housing density, Glasgow may be faced with a serious problem in her housing development, for the multi-storey development considered necessary may tend with its high housing density to nullify the beneficial effect on the incidence of tuberculosis that may derive from rehousing.

\section{SUMMARY}

Notifications of pulmonary tuberculosis in Glasgow during 1951 and 1952 are examined in relation to housing conditions in the 37 wards of the city. A more detailed examination is made of notifications during 1951 in two districts of the city: one

TABLE XI

CLASSIFICATION OF HOUSES

\begin{tabular}{|c|c|c|c|c|c|c|c|c|c|c|c|}
\hline \multirow{2}{*}{ District } & \multirow{2}{*}{\multicolumn{3}{|c|}{ Classification }} & \multicolumn{2}{|c|}{$\begin{array}{l}\text { Houses Occupied by } \\
\text { Tuberculous Families }\end{array}$} & \multicolumn{2}{|c|}{ All Houses Surveyed } & \multicolumn{2}{|c|}{ Tuberculous Cases } & \multicolumn{2}{|c|}{ Estimated Population } \\
\hline & & & & No. & Per Cent. & No. & Per Cent. & No. & Per Cent. & No. & Per Cent. \\
\hline \multirow[t]{2}{*}{$\mathbf{A}$} & 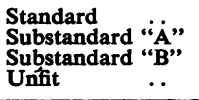 & $\begin{array}{l}\cdots \\
\cdots\end{array}$ & $\begin{array}{l}\ddot{*} \\
\ddot{*}\end{array}$ & $\begin{array}{l}17 \\
55 \\
58 \\
19\end{array}$ & $\begin{array}{l}11 \cdot 4 \\
36 \cdot 9 \\
38 \cdot 9 \\
12 \cdot 8\end{array}$ & $\begin{array}{l}1,721 \\
6,745 \\
6,695 \\
2,182\end{array}$ & $\begin{array}{r}9 \cdot 9 \\
38 \cdot 9 \\
38 \cdot 6 \\
12 \cdot 6\end{array}$ & $\begin{array}{l}19 \\
57 \\
60 \\
20\end{array}$ & $\begin{array}{l}12 \cdot 2 \\
36 \cdot 5 \\
38 \cdot 5 \\
12 \cdot 8\end{array}$ & $\begin{array}{r}7,435 \\
23,494 \\
23,215 \\
6,844\end{array}$ & $\begin{array}{l}12 \cdot 2 \\
38 \cdot 5 \\
38 \cdot 1 \\
11 \cdot 2\end{array}$ \\
\hline & Totals .. & $\cdots$ & $\cdots$ & 149 & $100 \cdot 0$ & 17,343 & $100 \cdot 0$ & 156 & $100 \cdot 0$ & 60,988 & $100 \cdot 0$ \\
\hline \multirow[t]{2}{*}{$\begin{array}{l}\text { Ward } 18 \\
\text { of } \\
\text { District } \\
B\end{array}$} & $\begin{array}{l}\text { Standard } \\
\text { Substandard “A”" } \\
\text { Substandard "B" } \\
\text { Unfit . } \\
\end{array}$ & $\begin{array}{l}\ddot{ } \\
\ddot{*} \\
\cdots\end{array}$ & $\begin{array}{l}\ddot{*} \\
\ddot{*}\end{array}$ & $\begin{array}{r}25 \\
17 \\
9 \\
-\end{array}$ & $\begin{array}{l}49 \cdot 0 \\
33 \cdot 3 \\
17 \cdot 7 \\
-\end{array}$ & $\begin{array}{r}2,945 \\
3,302 \\
727 \\
49\end{array}$ & $\begin{array}{r}41 \cdot 9 \\
47 \cdot 0 \\
10 \cdot 4 \\
0 \cdot 7\end{array}$ & $\begin{array}{r}26 \\
17 \\
9 \\
\end{array}$ & $\begin{array}{l}50 \cdot 0 \\
32 \cdot 7 \\
17 \cdot 3 \\
-\end{array}$ & $\begin{array}{r}11,960 \\
10,724 \\
2,325 \\
151\end{array}$ & $\begin{array}{r}47 \cdot 5 \\
42 \cdot 6 \\
9 \cdot 3 \\
0 \cdot 6\end{array}$ \\
\hline & Totals .. & . & $\cdots$ & 51 & $100 \cdot 0$ & 7,023 & $100 \cdot 0$ & 52 & $100 \cdot 0$ & 25,160 & $100 \cdot 0$ \\
\hline
\end{tabular}


(District A) with a high and the other (District B) with a low incidence of the disease.

(1) The ward incidence of the disease is significantly correlated with the number of rooms per house, the number of persons per room, and the percentage of the population living more than two persons per room, all of which are themselves highly correlated.

(2) The association between these overcrowding indices and ward incidence appears to be restricted to the 21 wards with case-rates less than the city rate; in the sixteen wards with case-rates greater than the city rate there is no significant correlation. In this latter group of wards, factors other than housing must be operative in influencing the case-rates.

(3) The mean number of persons per room for the 21 wards having case-rates less than the city rate was $1 \cdot 17$ (standard deviation $0 \cdot 289$ ) and the mean for the sixteen wards with case-rates higher than the city rate was 1.49 (standard deviation 0.226 ).

(4) In both District A and District B the average tuberculous household was found to be larger than the average in the area. It is suggested that this may be explained in terms of the high incidence of disease in the adolescent and young adult age group, Families with adolescent and young adult members are usually approaching their maximum size, and this must result in a greater degree of overcrowding in tuberculous families, especially in houses of one and two rooms.
(5) In District $A$, no association between the incidence of pulmonary tuberculosis with overcrowding was apparent, but the tuberculous household was larger than the average household in the area.

(6) In District B, on the other hand, there was an association between the incidence of pulmonary tuberculosis and overcrowding. However, the percentage of tuberculous households living in one and two rooms corresponded closely with the percentage of all households in the district living in one and two rooms (64.0 per cent. and 63.0 per cent. respectively), and no association was found with either the number of rooms in the tuberculous house or the number of rooms occupied by the tuberculous household. It would seem, therefore, that this association is merely the reflection of the larger size of the tuberculous household.

(7) When contact cases were investigated, no association with overcrowding was established, though the numbers were small and any conclusion must be reserved.

(8) No association was found between the incidence of pulmonary tuberculosis and the fitness or otherwise of a house for human habitation.

\section{REFERENCES}

Brett, G. Z., and Benjamin, B. (1957). British Journal of Preventive and Social Medicine, 11, 7.

McKinlay, P. L. (1947). Hlth Bull. Dept. Hlth, Scotland, 5, 37.

General Registry Office, Edinburgh (1952). "Census 1951, Vol. 1, Part 2, City of Glasgow". H.M.S.O., Edinburgh.

Stein, L. (1950). British Journal of Preventive and Social Medicine, 6, 1. 